\title{
Effect of antibiotic lavage in adhesion prevention in bacterial peritonitis
}

\author{
Bakteriyel peritonitte antibiyotikle lavajın adezyonu önlemede etkisi
}

\author{
Hüseyin Ayhan KAYAOĞLU, ${ }^{1}$ Namık ÖZKAN, ${ }^{1}$ Erdinç YENIDOĞAN, ${ }^{1}$ Reşid Doğan KÖSEOĞLU ${ }^{2}$
}

\section{BACKGROUND}

Intra-abdominal adhesions remain a major clinical problem. Previously, rifamycin lavage was used to prevent adhesion formation in the septic abdomen. The aim of our study was to test the effectiveness of intraperitoneal application of alternate antibiotics in an abdominal sepsis model.

\section{METHODS}

Sixty Wistar-albino rats were randomly divided into 6 equal groups. Bacterial peritonitis was induced using caecal ligation and puncture model in all groups. Group 1 was an untreated control. The peritoneum was lavaged with isotonic saline in Group 2, with imipenem in Group 3, with ceftriaxone in Group 4, with cefazolin in group 5 and with metronidazole in group 6. Four weeks after the surgery, intra-abdominal adhesions were graded, tensile strength of the adhesions was measured and histopathological examinations were performed.

\section{RESULTS}

Imipenem, ceftriaxone and cefazolin significantly reduced adhesion formation $(\mathrm{p}<0.001)$ with significantly reduced fibrosis scores $(p=0.013)$. Adhesion formation was greatest in the metronidazole treatment group. The breaking force of adhesions was significantly reduced in Groups 4 and $5(\mathrm{p}<0.001)$. Although, the inflammation scores were similar between groups $(p=0.058)$, grade 3 inflammation scores were only seen in control, saline and metronidazoletreatment groups.

\section{CONCLUSION}

According to these data, cephalosporins may be effective in preventing adhesion formation in septic abdomens. These antibiotics need to be evaluated in a clinical trial.

Key Words: Antibiotic; cefazolin; ceftriaxone; imipenem; intraabdominal adhesion; metronidazole; peritoneal lavage.

\begin{abstract}
$A M A C ̧$
Karıniçi yapışıklıklar halen ciddi bir problemdir. Geçmişte septik karında adezyon formasyonunu önlemek için sadece rifamisin lavajı denenmiştir. Bu çalışmanın amacı karın sepsis modelinde farklı antibiyotiklerin periton içine uygulamasının etkinliğini değerlendirmektir.
\end{abstract}

\section{GEREÇ VE YÖNTEM}

Altmış adet Wistar-albino sıçan rastgele olacak şekilde 6 eşit gruba ayrıldı. Tüm gruplara çekal ligasyon ve puncture modeli uygulanarak bakteriyel peritonit oluşturuldu. Grup 1 kontrol grubuydu. Grup 2'ye izotonik salinle, grup 3'e imipenemle, grup 4'e seftriaksonla, grup 5'e sefazolinle ve grup 6'ya metronidazolle periton lavajı yapıldı. Cerrahiden 4 hafta sonra karıniçi yapışıklık değerlendirildi, yapışıklıkların gerginlik kuvveti ölçüldü ve histopatolojik değerlendirme yapıldı.

\section{BULGULAR}

İmipenem, seftriakson ve sefazolin ile yapışıklık formasyonu anlamlı derecede azald $1(\mathrm{p}<0,001)$ ve fibrozis skorları anlamlı derecede düşük olarak bulundu $(p=0,013)$. En kötü yapışıklık metronidazol grubunda izlendi. Yapışıklık kopma kuvveti grup 4 ve 5 'te anlamlı olarak düşüktü ( $<<0,001)$. Enflamasyon dağılım skorları benzer olmasına rağmen $(p=0,058)$ grade 3 enflamasyon skorları sadece kontrol, salin ve metronidazol grubunda gözlemlendi.

\section{SONUÇ}

Bu veriler 1şı̆̆ında septik karında sefalosporinle peritoneal lavajın yapışıklığı önlenmede etkin olduğu ve sonuçların bir klinik çalışmada değerlendirilmesi gerektiği söylenebilir.

Anahtar Sözcükler: Antibiyotik; sefazolin; seftriakson; imipenem; karıniçi yapışıklık; metronidazol; peritoneal lavaj.
Departments of ${ }^{1}$ General Surgery, ${ }^{2}$ Pathology, Gaziosmanpasa University, Faculty of Medicine, Tokat, Turkey.
Gaziosmanpaşa Üniversitesi Tıp Fakültesi, 'Genel Cerrahi Anabilim Dalı, ${ }^{2}$ Patoloji Anabilim Dal, Tokat.

Correspondence (Illetişsim): Hüseyin Ayhan Kayaoğlu, M.D. Gaziosmanpaşa Üniversitesi Tıp Fakültesi, Genel Cerrahi Anabilim Dalı, Tokat, Turkey. Tel: +90 - 356 - 2133294 e-mail (e-posta): ayhankayaoglu@yahoo.com 
Intra-abdominal adhesions occur in approximately $95 \%$ of patients following abdominal surgery. Adhesions cause serious problems including chronic abdominal pain, intestinal obstructions, and female infertility. Certain conditions, such as intra-abdominal infections, aggravate this condition. Infectious conditions are associated with fibrin deposits, which may cause clinically significant adhesion and abscess formation with mortality rates as high as 17 to $38 \%$. ${ }^{[1-4]}$ Gram negative and anaerobic bacteria occur frequently in intra-abdominal infections and abscesses. Previously, systemic or local use of antibiotics have been evaluated for adhesion prevention properties. ${ }^{[5-8]}$ However, only rifamisin has been studied in experimental sepsis model. ${ }^{[9]}$

The aim of our study was to test the effectiveness of intraperitoneal application of various antibiotics in an experimental intra-abdominal sepsis model created by cecal ligation and puncture.

\section{MATERIALS AND METHODS}

\section{Subjects and surgery}

After the approval of the institutional ethical committee (approval code 03-GEKTIP-007), 60 adult, male, Wistar-albino rats $(250-300 \mathrm{~g})$ provided by the Experimental Research Laboratory of the University under standard husbandry conditions, were randomly divided into 6 equal groups. Animals were operated on at a room temperature of $20^{\circ} \mathrm{C}$ under $75 \mathrm{mg} / \mathrm{kg}$ ketamine hydrochloride with $5 \mathrm{mg} / \mathrm{kg}$ xylazine anesthesia was injected intramuscularly. After cleaning the skin, the anterior abdominal wall was shaved, treated with $10 \%$ povidon iodine, and a $3-\mathrm{cm}$ median laparotomy was performed. Bacterial peritonitis was induced using a caecal ligation and puncture (CLP) model in all groups ${ }^{[10]}$ The cecum was punctured on the antimesenteric border with an 18-gauge needle after ligation below the ileocecal valve. Six hours later, following repeat laparotomy, the caecum was resected and the peritoneum was lavaged with isotonic saline (Mediflex; Eczacibasi-Baxter Hastane Urunleri, Ayazaga, Istanbul, Turkey) in Group 2, with $50 \mathrm{mg} / \mathrm{kg}$ imipenem (Tienam $500 \mathrm{mg}$ IV Flakon, Merck Sharp \& Dohme Ilac, Esentepe, Istanbul, Turkey) in Group 3, with 100 $\mathrm{mg} / \mathrm{kg}$ ceftriaxone (Forsef Flakon; Bilim Ilac, Gebze, Kocaeli, Turkey) in Group 4, with $50 \mathrm{mg} / \mathrm{kg}$ cefazolin (Cefamezin Flakon; Eczacibasi Ilac, Luleburgaz, Kırklareli, Turkey) in Group 5 and with $40 \mathrm{mg} / \mathrm{kg}$ metronidazole (Flagyl enjektabl solusyon $0.5 \%$; Eczacibasi Ilac, Luleburgaz, Kurklareli, Turkey) in Group 6. These doses were chosen based on the manufacturer's recommendation using the appropriate surface area-dosage conversion factor of seven from man to rat. Group 1 served as control and peritoneal lavage was not performed in this group. All animals were resuscitated with $10 \mathrm{ml}$ saline subcutaneously in divided doses.
Rats were sacrificed by high dose pentothal injection four weeks after the surgery. After performing a U-type incision to the anterior abdominal wall, the adhesions were evaluated. A numerical score described by Knightly et al. ${ }^{[11]}$ was used to determine the adhesion grading by a surgeon unaware of the study groups (Table 1). After the grading of adhesions, the tensile strength of adhesions between abdominal organs was measured by the help of tensile testing equipment (Mark-10 Corporation, NY, USA), in which the test material was placed between a moveable arm over a stationary and a fixed arm connected to the balance with metal clips, by the same independent surgeon. By stretching the moveable arm gradually at speed of $10 \mathrm{~mm} / \mathrm{min}$, strength was applied and breaking force values at the time of disruption were detected in Newtons $(\mathrm{N})$.

\section{Histopathology}

Histopathological evaluations were performed by light microscopy with a magnification power of $100 \mathrm{x}$ and 400x. The resected adherent tissues were fixed in formaldehyde, embedded in paraffin blocks, and $4 \mu \mathrm{m}$ sections were stained with haematoxylin and eosin (H\&E). A pathologist, who was blind to the groups, graded the extent of fibrosis and inflammation in each specimen with a semi-quantitative scoring system (Tables 2 and 3). ${ }^{[12]}$

Table 1. Adhesion grading scale $e^{[11]}$

\begin{tabular}{cl}
\hline Score & Adhesion \\
\hline 0 & No adhesions \\
1 & Filmy adhesions \\
2 & Definite localized adhesions \\
3 & Dense multiple visceral adhesions \\
4 & Dense adhesions extending to abdominal wall \\
\hline
\end{tabular}

Table 2. Fibrosis grading scale ${ }^{[12]}$

\begin{tabular}{cl}
\hline Score & Amount of fibrosis \\
\hline 0 & None \\
1 & Minimal, loose \\
2 & Moderate \\
3 & Florid, dense \\
\hline
\end{tabular}

Table 3. Inflammation grading scale ${ }^{[12]}$

\begin{tabular}{|c|c|}
\hline Score & Amount of inflammation \\
\hline 0 & None \\
\hline 1 & $\begin{array}{l}\text { Giant cells, occasional lymphocytes, and } \\
\text { plasma cells }\end{array}$ \\
\hline 2 & $\begin{array}{l}\text { Giant cells, plasma cells, eosinophils, } \\
\text { neutrophils }\end{array}$ \\
\hline 3 & Many inflammatory cells, microabscesses \\
\hline
\end{tabular}




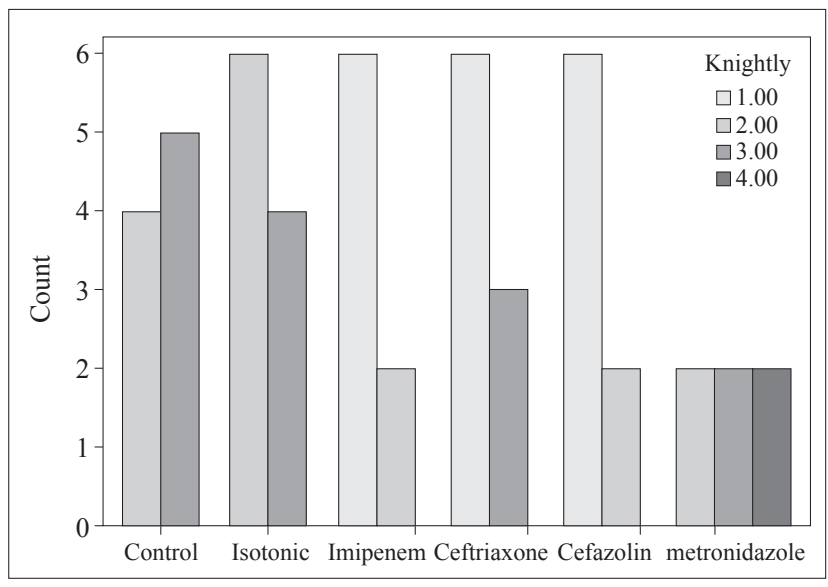

Fig. 1. Peritoneal lavage with imipenem, ceftriaxone and cefazolin significantly reduced adhesion formation by comparison to the other groups. Control and isotonic saline groups showed similar distributions. The most adhesions were present in the metronidazole treatment group $(\mathrm{p}<0.001)$.

\section{Statistical evaluation}

Chi-square tests (likelihood ratios) were used to assess differences in mortality, adhesion, fibrosis, and inflammation grades. One-way ANOVA following Tukey's test was used for evaluation of tensile strength of the adhesions. Differences with a value of $p<0.05$ were accepted as significant.

\section{RESULTS}

Ten rats from Groups 1, 3, 4, 5, and 6 died $(n=1,2$, $1,2,4$, respectively) on the postoperative first and second days. Autopsy was compatible with peritonitis including findings of dilated bowel loops and large volumes of peritoneal fluid in all animals. Although the highest mortality was seen in Group 6, the differences did not reach statistical significance $(\mathrm{p}=0.180)$. These

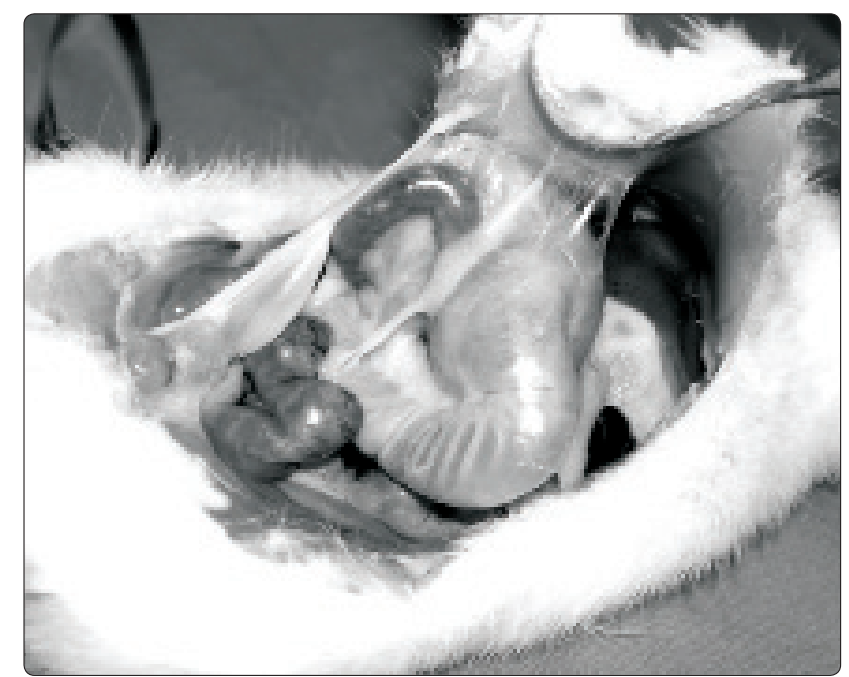

Fig. 2. Dense adhesions between abdominal organs and abdominal wall in an animal in Group 6. mortalities were excluded while performing other statistical analyses. Distribution of adhesion grading scores among groups was significantly different ( $<<0.001$, Fig. 1). Peritoneal lavage with imipenem, ceftriaxone, and cefazolin significantly reduced adhesion formation compared to the other groups. Control and isotonic saline groups exhibited similar rates of adhesion formation. The most severe adhesions were observed in the metronidazole group (Fig. 2).

Mean and standard deviation values for the breaking force of adhesions between organs of the study groups are shown in Table 4. The differences were statistically significant $(p<0.001)$. In paired comparisons of the groups, Groups 4 and 5 were significantly different from groups 1,2 and $6(p=0.037,0.026$, and $<0.001$, respectively, compared with Group 4 and $\mathrm{p}=0.025,0.018$, and $<0.001$, respectively, compared with Group 5). Although imipenem treatment did not result in significant improvement compared with the control and saline groups, the improvement was significant when compared to metronidazole. Fibrosis and inflammation grading scores among groups are shown in Figures 3 and 4. Fibrosis scores were statistically different between groups $(p=0.013)$. Significantly decreased fibrosis scores were observed in the imipenem, ceftriaxone, and cefazolin groups. The highest fibrosis scores were seen in the control and metronidazole groups. Although the distribution of the inflammation scores were similar $(\mathrm{p}=0.058)$, grade 3 inflammation scores were only seen in the control, saline, and metronidazole groups. Imipenem, ceftriaxone and cefazolin groups showed no inflammation or moderate inflammation scores (Fig. 5).

\section{DISCUSSION}

Adhesions remain a major clinical challenge with serious complications including chronic pain, bowel

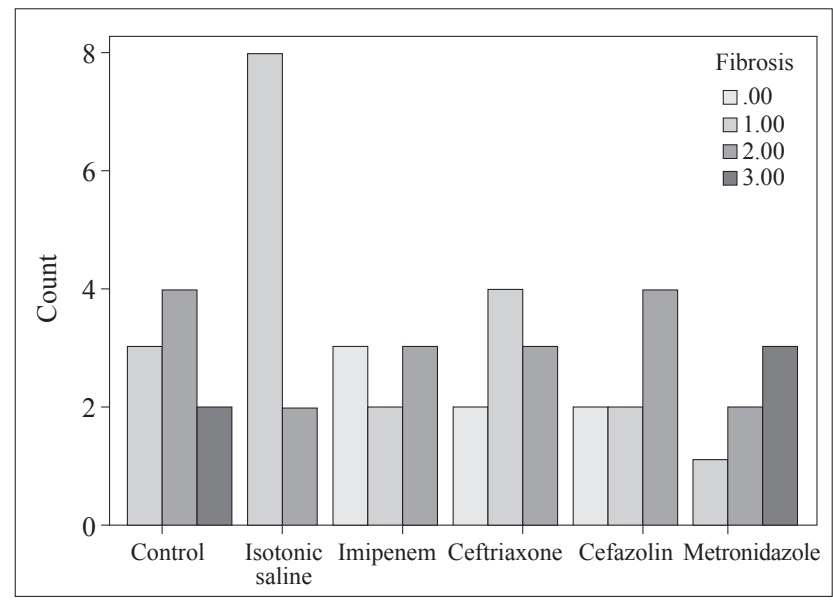

Fig. 3. Significantly reduced fibrosis scores were observed in imipenem, ceftriaxone and cefazolin groups. Highest scores were seen in control and metronidazole groups $(p=0.013)$. 
Table 4. Breaking force of adhesions between organs according to study group

\begin{tabular}{lcc}
\hline Group & $\mathrm{n}$ & Mean $\pm \mathrm{SD}$ \\
\hline Control & 9 & $0.2222 \pm 0.0565$ \\
Isotonic saline & 10 & $0.2250 \pm 0.1136$ \\
Imipenem & 8 & $0.1838 \pm 0.1185$ \\
Ceftriaxone & 9 & $0.0778 \pm 0.0417 *$ \\
Cefazolin & 8 & $0.0663 \pm 0.0443^{*}$ \\
Metronidazole & 6 & $0.3583 \pm 0.1801$ \\
Total & 50 & $0.1820 \pm 0.1321$ \\
\hline
\end{tabular}

$\mathrm{p}<0.001$; Cefazolin and ceftriaxone significantly reduced tensile strength of adhesions when compared to control, isotonic saline and metronidazole groups. Although, imipenem did not show significant improvement relative to control and saline treatment groups, the decrease was significant when compared to metronidazole.

obstruction, or infertility. Some patients require repeat surgeries to address these complications. The duration of surgery, previous surgical history, peritonitis, bowel perforations, and emergency surgery increase complication incidence. Surgeries of the colon and rectum are associated with increased risk of adhesion-related problems relative to surgeries of the small bowel, appendix, or gallbladder. Intra-abdominal infections and subsequent peritonitis are associated with fibrin deposits, which may cause clinically significant adhesion and abscess formation. ${ }^{[13,14]}$ We used the CLP model to simulate this clinical situation. No systemic antibiotic was administrated in our study in order to specifically evaluate the local effects of the antibiotics.

Adhesions are formed when the peritoneum is damaged and the basal membrane of the mesothelial layer is exposed to the surrounding tissues. This injury to the peritoneum causes a local inflammatory response, which leads to the formation of a serosanguineous, fibrin-rich exudate as part of the haemostatic process.

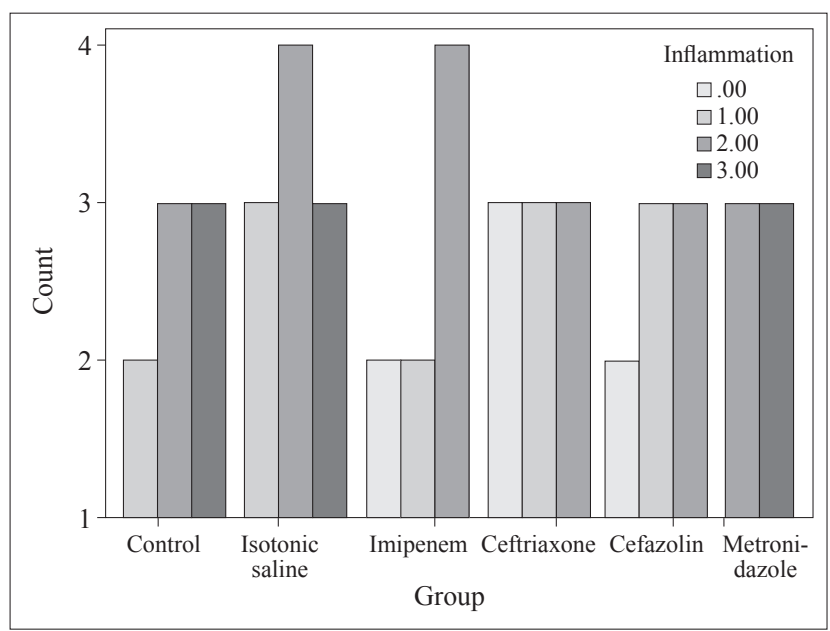

Fig. 4. Although, the distribution was similar between groups $(p=0.058)$, grade 3 inflammation scores were only seen in control, saline and metronidazole treatment groups.
Inflammatory response occurs simultaneously with the activation of the coagulation cascade. This activation results in thrombin formation, which is necessary for the conversion of fibrinogen to fibrin. ${ }^{[15,16]}$ Fibrin fulfills a temporary role in tissue repair. Resolution of the fibrin deposits is essential for proper restoration of preoperative, non-inflamed conditions. When fibrin deposit persist, fibrin provides a matrix for invading fibroblasts and new blood vessels, and the deposited fibrin becomes organized, permanent adhesions, characterized by the deposition of collagen and vascular ingrowth. The degradation of fibrin is regulated by the fibrinolytic system. Inflammatory mediators play an important role in this period. Several different cell types, cytokines, coagulation factors and proteases interact in biochemical events and control the adhesion formation process. ${ }^{[17]}$ Early fibrinolysis, within 5 days of surgery, decreases adhesion formation. If early fibrinolysis does not occur, the temporary fibrin matrix persists and gradually becomes more organized as collagen-secreting fibroblasts, leading to adhesion formation. ${ }^{[18,19]}$ Intra-abdominal infections severely disrupt fibrinolysis, as evidenced by the high levels of plasminogen activator inhibitor in peritoneal tissue and fluid. ${ }^{[20]}$ Peritoneal injury caused by bacteria results in accumulation of an inflammatory exudate that leads to fibrin deposition, resulting in fibrinous adhesions between adjacent organs. ${ }^{[21]}$ In addition, invasion of fibroblasts at infection sites leads to deposition of collagen and subsequent formation of permanent fibrous adhesions. ${ }^{[22]}$

Peritoneal lavage in the treatment of intra-abdominal infections is widely studied but its benefits are unclear. Although lavage is generally considered a safe procedure, there are some objections to its use. Ability of removing bacteria from the peritoneal cavity and serving as adjuvant substance of peritoneal

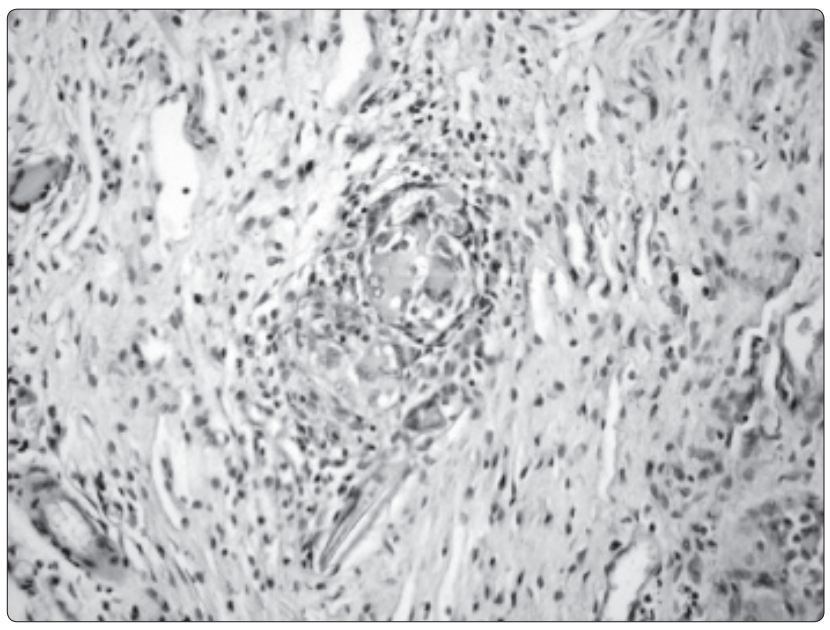

Fig. 5. Florid fibrosis and grade 2 inflammation with giant cell formation in an animal in the metronidazole treated group. 
fluid itself for defense mechanisms are the major origins of the objections. The ideal peritoneal lavage solution should be highly effective, with no mortality, and result in low incidence of adhesion formation. ${ }^{[23-25]}$ To date, there is no universally accepted method for peritoneal lavage. Some researchers have demonstrated that peritoneal lavage with saline, antibiotics, or fibrinolytic agent solutions does not influence outcome following laparotomies for peritonitis. Other reports indicate that peritoneal lavage promotes adhesion formation, as opposed to reports that suggested a preventive role for peritoneal lavages in adhesion formation. ${ }^{[26-28]}$ Antibiotics can exert their anti-adhesive effects by inhibition of synthesis or expression of adhesins on the bacterial cell surface, or modify bacterial protein expression in such a way as to interfere with the ability of the microorganisms to approach receptors on animal cell surface. ${ }^{[29]}$ Sortini et al. ${ }^{[5]}$ compared the efficacy of peritoneal lavage with chloramphenicol, clindamycin, piperacillin, tobramycin, ceftriaxone and imipenem-cilastatin to saline, with adhesion formation increased in study groups. Jallouli et al. ${ }^{[9]}$ used rifamycin for peritoneal lavage in a peritonitis model and demonstrated significantly reduced adhesion formation and higher survival rate. On the other hand, in the study by Rappaport et al., ${ }^{[23]}$ cefazolin and tetracycline irrigation increased peritoneal adhesion formation in the non-septic abdomen. We evaluated cefazolin, ceftriaxone, imipenem and metronidazole for peritoneal lavage in a peritonitis model. These antibiotics have clinical efficacy against a wide variety of organisms, including gram-positive aerobic cocci, gram-negative aerobes and most penicillin-susceptible anaerobes. Ceftriaxone has enhanced activity against Enterobacteriaceae associated with hospital-acquired infections. Imipenem is particularly important for its activity against Pseudomonas aeruginosa and the Enterococcus species. Metronidazole is a nitroimidazole antibiotic used against anaerobic bacteria and protozoa. These compounds have wide area of usage in daily general surgical practice for both prophylaxis and treatment, with a low side-effect profile. ${ }^{[30-32]}$ Peritoneal lavage with imipenem, ceftriaxone and cefazolin significantly reduced the adhesion formation relative to the other groups. In addition, adhesions were weak in cefazolin and ceftriaxone groups, with significantly reduced adhesion breaking force by comparison to other groups with the exception of imipenem. Fibrosis scores were also significantly reduced in the same groups. Although the inflammation scores were statistically similar, control, saline and metronidazole treatment groups exhibited the highest scores. Cahill et al. ${ }^{[33]}$ demonstrated that enteric bacteria and their antigens stimulated subsequent adhesion formation after laparotomy. Differing from epithelial restoration, mesothelial regeneration after injury represents a form of secondary wound healing, and such reparative processes are markedly influenced by bacterial contamination. Gut-associated microbes and their antigens (in particular endotoxin/lipopolysaccharide) may directly induce a peritoneal inflammatory reaction through activation of resident peritoneal cells. Cephalosporins and imipenem induce cell wall synthesis disorders in bacteria, fimbria loss and a decrease in the expression of elements responsible for adhesion on the surface of bacterial cells. ${ }^{[34]}$ Adhesion is considered to be the first step in the sequence of events leading to colonization, and is an important determinant of virulence and subsequent infection. The effect of antibiotics on adhesion may be strain specific and various antibiotics may have varying effects on bacterial adhesion properties. ${ }^{[35]}$ We hypothesize that the higher adhesion rate in the group treated with metronidazole was the result of the overgrowth of aerobic bacteria, especially gram negatives, rather than a direct effect of metronidazole itself.

In conclusion, according to these data, metronidazole should not be recommended for peritoneal lavage. Cephalosporins seem to be effective in preventing adhesion formation in septic abdomens and should be evaluated in a clinical trial.

Conflict-of-interest issues regarding the authorship or article: None declared.

\section{REFERENCES}

1. Ellis H, Moran BJ, Thompson JN, Parker MC, Wilson MS, Menzies D, et al. Adhesion-related hospital readmissions after abdominal and pelvic surgery: a retrospective cohort study. Lancet 1999;353:1476-80.

2. Jeekel H. Cost implications of adhesions as highlighted in a European study. Eur J Surg Suppl 1997;579:43-5.

3. Tito WA, Sorr MG. Intestinal obstructions. In: Zuidema GD, Nyhus LM, editors. Shakelford's surgery of alimentary tract. 5th ed. Philadelphia: Saunders; 1996. p. 375-416.

4. Christou NV, Barie PS, Dellinger EP, Waymack JP, Stone HH. Surgical Infection Society intra-abdominal infection study. Prospective evaluation of management techniques and outcome. Arch Surg 1993;128:193-9.

5. Sortini D, Feo CV, Maravegias K, Carcoforo P, Pozza E, Liboni A, et al. Role of peritoneal lavage in adhesion formation and survival rate in rats: an experimental study. J Invest Surg 2006;19:291-7.

6. Cohen BM, Heyman T, Mast D. Use of intraperitoneal solutions for preventing pelvic adhesions in the rat. J Reprod Med 1983;28:649-53.

7. Phillips RK, Dudley HA. The effect of tetracycline lavage and trauma on visceral and parietal peritoneal ultrastructure and adhesion formation. Br J Surg 1984;71:537-9.

8. Oncel M, Kurt N, Remzi FH, Sensu SS, Vural S, Gezen CF, et al. The effectiveness of systemic antibiotics in preventing postoperative, intraabdominal adhesions in an animal model. J Surg Res 2001;101:52-5.

9. Jallouli M, Hakim A, Znazen A, Sahnoun Z, Kallel H, Zghal $\mathrm{K}$, et al. Rifamycin lavage in the treatment of experimental intra-abdominal infection. J Surg Res 2009;155:191-4.

10. Wichterman KA, Baue AE, Chaudry IH. Sepsis and septic 
shock--a review of laboratory models and a proposal. J Surg Res 1980;29:189-201.

11. Knightly JJ, Agostino D, Cliffton EE. The effect of fibrinolysin and heparin on the formation of peritoneal adhesions. Surgery 1962;52:250-8.

12. Hooker GD, Taylor BM, Driman DK. Prevention of adhesion formation with use of sodium hyaluronate-based bioresorbable membrane in a rat model of ventral hernia repair with polypropylene mesh--a randomized, controlled study. Surgery 1999;125:211-6.

13. Blacker CM, Diamond MP. Pelvic adhesions and infertility. In: Seibel MM editor. Infertility: a comprehensive text. 2nd ed. Stamford, CT: Appleton \& Lange; 1997. p. 655-68.

14. Cheong YC, Laird SM, Li TC, Shelton JB, Ledger WL, Cooke ID. Peritoneal healing and adhesion formation/reformation. Hum Reprod Update 2001;7:556-66.

15. Holmdahl L, Ivarsson ML. The role of cytokines, coagulation, and fibrinolysis in peritoneal tissue repair. Eur J Surg 1999; 165:1012-9.

16. Reed KL, Fruin AB, Bishop-Bartolomei KK, Gower AC, Nicolaou M, Stucchi AF, et al. Neurokinin-1 receptor and substance P messenger RNA levels increase during intraabdominal adhesion formation. J Surg Res 2002;108:165-72.

17. Hellebrekers BW, Kooistra T. Pathogenesis of postoperative adhesion formation. Br J Surg 2011;98:1503-16.

18. Reijnen MM, Bleichrodt RP, van Goor H. Pathophysiology of intra-abdominal adhesion and abscess formation, and the effect of hyaluronan. Br J Surg 2003;90:533-41.

19. Sulaiman H, Dawson L, Laurent GJ, Bellingan GJ, Herrick SE. Role of plasminogen activators in peritoneal adhesion formation. Biochem Soc Trans 2002;30:126-31.

20. van Goor H, de Graaf JS, Grond J, Sluiter WJ, van der Meer J, Bom VJ, et al. Fibrinolytic activity in the abdominal cavity of rats with faecal peritonitis. Br J Surg 1994;81:1046-9.

21. van Goor H, Bom VJ, van der Meer J, Sluiter WJ, Bleichrodt RP. Coagulation and fibrinolytic responses of human peritoneal fluid and plasma to bacterial peritonitis. Br J Surg 1996;83:1133-5.

22. Thompson JN, Whawell SA. Pathogenesis and prevention of adhesion formation. Br J Surg 1995;82:3-5.

23. Rappaport WD, Holcomb M, Valente J, Chvapil M. Antibiotic irrigation and the formation of intraabdominal adhesions.
Am J Surg 1989;158:435-7.

24. Reijnen MM, Meis JF, Postma VA, van Goor H. Prevention of intra-abdominal abscesses and adhesions using a hyaluronic acid solution in a rat peritonitis model. Arch Surg 1999;134:997-1001.

25. el-Ghoul W. The effects of combined liquid and membrane barriers in prevention of post-operative intra-abdominal adhesions after experimental jejunal anastomosis in dogs. Dtsch Tierarztl Wochenschr 2005;112:3-10.

26. Kayaoglu HA, Ozkan N, Hazinedaroglu SM, Ersoy OF, Koseoglu RD. An assessment of the effects of two types of bioresorbable barriers to prevent postoperative intra-abdominal adhesions in rats. Surg Today 2005;35:946-50.

27. Kirdak T, Uysal E, Korun N. Assessment of effectiveness of different doses of methylprednisolone on intraabdominal adhesion prevention. Ulus Travma Acil Cerrahi Derg 2008; 14:188-91.

28. Günaydın M, Güvenc D, Yıldız L, Aksoy A, Tander B, Bicakci U, et al. Comparison of substances used for prevention of intra-abdominal adhesions: an experimental study in rats. Türkiye Klinikleri J Med Sci 2012;32:337-45.

29. Lorian V, Ernst J. Effects of antibiotics on bacterial structure and their pathogenicity. Pathol Biol (Paris) 1987;35:1370-6.

30. Ikawa K, Morikawa N, Sakamoto K, Ikeda K, Ohge H, Takesue $\mathrm{Y}$, et al. Pharmacokinetics and pharmacodynamic assessment of imipenem in the intraperitoneal fluid of abdominal surgery patients. Chemotherapy 2008;54:131-9.

31. Abad CL, Kumar A, Safdar N. Antimicrobial therapy of sepsis and septic shock--when are two drugs better than one? Crit Care Clin 2011;27:1-27.

32. Weigelt JA. Empiric treatment options in the management of complicated intra-abdominal infections. Cleve Clin J Med 2007;74:29-37.

33. Cahill RA, Wang JH, Redmond HP. Enteric bacteria and their antigens may stimulate postoperative peritoneal adhesion formation. Surgery 2007;141:403-10.

34. Zalas-Wiecek P, Gospodarek E, Piecyk K. Influence of subinhibitory concentrations of cefotaxime, imipenem and ciprofloxacin on adhesion of Escherichia coli strains to polystyrene. Pol J Microbiol 2011;60:345-9.

35. Shibl AM. Effect of antibiotics on adherence of microorganisms to epithelial cell surfaces. Rev Infect Dis 1985;7:51-65. 